\title{
塞業系サイディングの耐凍害性に関する屋外暴露実験 OUTDOOR EXPOSURE TEST ON FROST RESISTANCE OF FIBER REINFORCED CEMENT SIDINGS
}

\author{
吉野利 幸*, 桂修**, 松村 宇***, 谷口内*** \\ Toshiyuki YOSHINO, Osamu KATSURA, Takashi MATSUMURA \\ and Madoka TANIGUCHI
}

The purpose of this paper is to clarify the frost resistance of fiber reinforced cement sidings through an outdoor exposure test, and the relation between the results of the outdoor exposure test and the results of the accelerated freezing and thawing test on frost resistance. The outdoor exposure test was carried out at Sapporo, Kamiiso and Kitami for 10 years, and the accelerated test was performed according to JIS A 5422-1995. 21 kinds of sidings which differ in production methods and raw materials were prepared. The results obtained may be summarized as follows: 1) Sidings having a apparent density above $1.2 \mathrm{~g} / \mathrm{cm}^{3}$ are durable to freezing and thawing action in outdoor exposure test and accelerated test. Also sidings containing air-void, preformed cellular plastic spherical materials and wood flake are durable.

2) The results of the outdoor exposure test are not consistent with the results of the accelerated test. It is surmised that there are affectable factors on frost resistance which are not taken account in the accelerated test.

Keywords : outdoor exposure test, fiber reinforced cement sidings, frost resistance

屋外暴露試験, 䆛業系サイディング, 耐凍害性

\section{1.はじめに}

案業系サイディング(以下サイディングと言う)は乾式材料である ため温度環境に左右されずに施工が可能で，色やテクスチャーなど の表面デザインが曹富であるほか価格も手ごろであることから，約 7 割の新築戸建住宅の外蓑材として利用されているリ。しかし，寒冷 地では吸水して含水が高まると凍害を生じる場合があり，外壁の美 観を損ねたり耐久性を低下させる要因となる。建物の長寿命化を図 っていくうえで外壁の高耐久化の意義は大きく，このため，外壁材と して多くの優位性を有し，今後も主要な材料として使用されていく と思われるサイディングの耐凍害性向上の追求は重要である。

本研究の最終目的は，屋外環境でのサイディング谏害劣化の予溉 方法を提案し，耐凍害性に俊れるサイディングの開発やサイディン グ外壁の耐久設計に资することにあるが，そのためには，サイディン グの耐凍害性がどのような環境要因の影響を受けるかを明らかにす る必要がある。本論文は，その第一段階として，(1)屋外環境下でのサ イディング耐凍害性，(2)屋外環境下での結果と促進凍結融解試験結 果との対応性を明らかにすることを目的に，屋外暴露試験および促 進凍結融解試験を実施し，考察を加えたものである。

サイディングの耐凍害性に関する既往の研究は，ほとんどが促進 試験によるもの 2)で，屋外暴露試験によるものは星野3により行わ れた質量変化に関する報告があるのみで，屋外環境下での耐凍害性 に関する公表されたデー夕は筆者の知る限りない。

\section{2. 実験方法}

\section{1 実験に使用したサイディング}

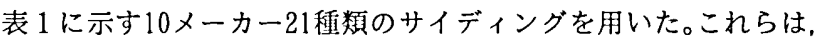
平成 7 年に札猊市内で市販されていたものまたはメーカーから入手 したもので, 試験体番号 4 はハウスメーカー向けに試作されたもので あり，試験体番号10はメーカーが使用地域を温暖地に限定したもの である。成形法別では抄造法が 11 種類, 押出法が 7 種類, マット成 形法が 3 種類で, 厚さは12〜18mmである。善生方法別では, 湿熱善 生が 9 種類.オートクレーブ養生が 12 種類である。なお，試験体番 号14 には最大直径で $1.5 \mathrm{~mm}$ 程度の気泡が, 試験体番号 16 には同程度 の寸法の塩ビ製と思われる球状の発泡体が混入されている。試験体 19 21には質量割合で15\%以上の木質原料が混入されている。

サイディングの物理試験結果を表 1 にあわせて示す。このうち空陌 率は, 水銀王入法の加圧過程で测定される直径 $129 \mu \mathrm{m} \sim 6.3 \mathrm{~nm}$ の笙 囲の空隙を対象として算出された值である。

\section{2 促進凍桔融解試験}

JIS A 5422-1995(窯業系サイディング)に準じて促進凍結融解試験 を実施した。ただし、本実験では、サイディング素材の耐凍害性を評 価するという锣点から、試験体の切断小口面のシールは行わなかっ た。試験体数は 1 種類につき 2 個とした。

促進凍結融解試験は200サイクルまで実施し，約 33 サイクルごと に試験体の外観観察, 厚さおよび質量の測定を行った。表面はく離と

\footnotetext{
本諭文の一部は，文辩8)で発装している。

* 北旅道立北力建築総合研究所 主任研究吕・博士(工学)

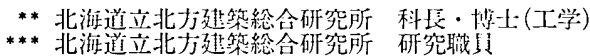

Senior Research Officer, Hokkaido Northern Regional Research Building Inst. Ph. D.

Chief, Hokkaido Northern Regional Research Building Inst., Ph. D

Researcher, Hokkaido Northern Regional Research Building Inst. 
表 1 実験に使用したサイディングの種類及び物理性能試験結果

\begin{tabular}{|c|c|c|c|c|c|c|c|c|}
\hline \multirow{2}{*}{$\begin{array}{l}\text { 成 } \\
\text { 形 } \\
\text { 法 }\end{array}$} & \multirow{2}{*}{$\begin{array}{l}\text { 試験 } \\
\text { 体 } \\
\text { 番号 }\end{array}$} & \multirow[b]{2}{*}{ 㕠生方法 } & \multirow{2}{*}{$\begin{array}{c}\text { 見掛认 } \\
\text { 密度 } \\
\left(\mathrm{g} / \mathrm{cm}^{3}\right)\end{array}$} & \multirow[b]{2}{*}{$\begin{array}{c}\text { 吸水率 } \\
(\%)\end{array}$} & \multicolumn{2}{|c|}{ 強さ } & \multirow[b]{2}{*}{$\begin{array}{l}\text { 空隙率 } \\
\text { (cc/g) }\end{array}$} & \multirow[b]{2}{*}{ 備 考 } \\
\hline & & & & & $\begin{array}{c}\text { 曲げ } \\
\left(\mathrm{N} / \mathrm{mm}^{2}\right)\end{array}$ & $\begin{array}{c}\text { 平面引張 } \\
\left(\mathrm{N} / \mathrm{mm}^{2}\right)\end{array}$ & & \\
\hline \multirow{11}{*}{ 抄 } & 1 & オートクレーブ & 1.09 & 46.1 & 12.73 & 1.52 & 0.51 & \\
\hline & 2 & オートタレーブ & 1.10 & 44.3 & 11.90 & 1.36 & 0.46 & \\
\hline & 3 & 湿熱 & 1.14 & 46.0 & 12.97 & 1.40 & 0.48 & \\
\hline & 4 & 湿熱 & 1.04 & 26.4 & 10.98 & 0.75 & 0.51 & \\
\hline & 5 & オートクレーブ & 1.19 & 44.3 & 12.01 & 1.40 & 0.43 & \\
\hline & 6 & 湿熱 & 1.12 & 44.8 & 7.47 & 0.76 & 0.45 & \\
\hline & 7 & 湿熱 & 0.96 & 36.6 & 8.22 & 1.48 & 0.56 & \\
\hline & 8 & 湿熱 & 1.03 & 52.8 & 11.06 & 1.40 & 0.52 & \\
\hline & 9 & 湿熱 & 0.98 & 50.9 & 10.93 & 0.63 & 0.53 & \\
\hline & 10 & オートクレーブ & 0.89 & 61.3 & 9.10 & 0.86 & 0.74 & \\
\hline & 11 & 湿熱 & 1.64 & 29.4 & 19.35 & 5.43 & 0.14 & \\
\hline \multirow{7}{*}{ 押 } & 12 & オートクレーブ & 0.96 & 41.5 & 7.94 & 2.09 & 0.64 & \\
\hline & 13 & オートタレーブ & 1.05 & 35.5 & 5.20 & 1.43 & 0.47 & \\
\hline & 14 & オートクレーブ & 0.98 & 42.9 & 6.75 & 3.04 & 0.60 & 気泡混入 \\
\hline & 15 & オートクレープ & 1.07 & 47.1 & 6.03 & 2.81 & 0.51 & \\
\hline & 16 & オートタレープ & 1.00 & 34.6 & 6.78 & 1.17 & 0.50 & $\begin{array}{c}\text { 盐ビ発泡 } \\
\text { 体混入 } \\
\end{array}$ \\
\hline & 17 & オートクレーブ & 1.04 & 53.4 & 9.02 & 2.54 & 0.54 & \\
\hline & 18 & オートクレープ & 1.38 & 34.6 & 6.55 & 4.25 & 0.14 & \\
\hline \multirow{3}{*}{$\begin{array}{l}\nabla \\
y \\
r\end{array}$} & 19 & オートクレーブ & 1.11 & 21.4 & 10.12 & 1.08 & 0.37 & \multirow{3}{*}{$\begin{array}{l}\text { 木啠原料 } \\
15 \% \text { 上 } \\
\text { 混入 }\end{array}$} \\
\hline & 20 & 湿熱 & 1.30 & 21.8 & 14.33 & 1.42 & 0.28 & \\
\hline & 21 & 湿熱 & 1.21 & 19.2 & 8.92 & 0.71 & 0.42 & \\
\hline
\end{tabular}

㬝間はく離を対象として外観観察を行い，小ロに明らかな隙間を生じ た場合を「著しい層間はく離あり」とした。

\section{3 屋外暴露試験}

\section{(1) 試験体および暴露方法}

暴露試験体の寸法は，長さ $300 \mathrm{~mm} \times$ 幅 $100 \mathrm{~mm}$ で，試験体数は各 3 個 とし, 促進凍結融解試験の場合と同様の考えから切断木口面のシー ルは行わなかった。試験体を24時間水中浸せきした後, 温度 $20^{\circ} \mathrm{C}$ 湿 度 $60 \%$ の恒温恒湿室内に 7 日間放直し，その後厚さおよび質量测定 を行い，暴露試験に供した。

暴露方法は南正面30度傾斜の直接暴露とした。暴露装路の試験体 受け枠は雨水や融雪水が溜まるような形状になっている。試験体の 取付方法を図 1 に，暴露試験状況を写真 1 に示す。

(2) 暴露場所および暴露期間

暴露場所は北海道内の札幌市，上磯町(現在名は北斗市)，北見市 の3か所で，いずれも R C 造建物の屋根スラブ上である。

暴露期間は平成 7 年 9 月〜 17 年 6 月までの約 10 年間である。

(3) 試験体の测定

試験体の測定は 5 月頃に行い，6年目までは毎年，その後は 1 年お きとした。測定項目は目視による外钼観察，厚さおよび質量とした。 厚さの测定か所は，試験体の下辺から $20 \mathrm{~mm}$ の位置で両辺から $20 \mathrm{~mm} の$ 2 か所および中央の 1 か所の合計 3 か所とした。厚さおよび質量測 定に先立ち，試験体を 7 日間温度 $20{ }^{\circ} \mathrm{C}$ 湿度 $60 \%$ の恒温恒湿室内に放 置した。

また，温度測定用試験体のほぼ中央部の側面から埋め込んだ熱電 対により毎正時の試験体温度を测定し，冬期間(10月 1 日〜 4 月 30 日）に試験体に生じる凍結融解回数を求めた。最低温度が-1.0 下で最高温度が $0{ }^{\circ} \mathrm{C}$ 以上になるまでを 1 回の凍結融解とし，凍結時

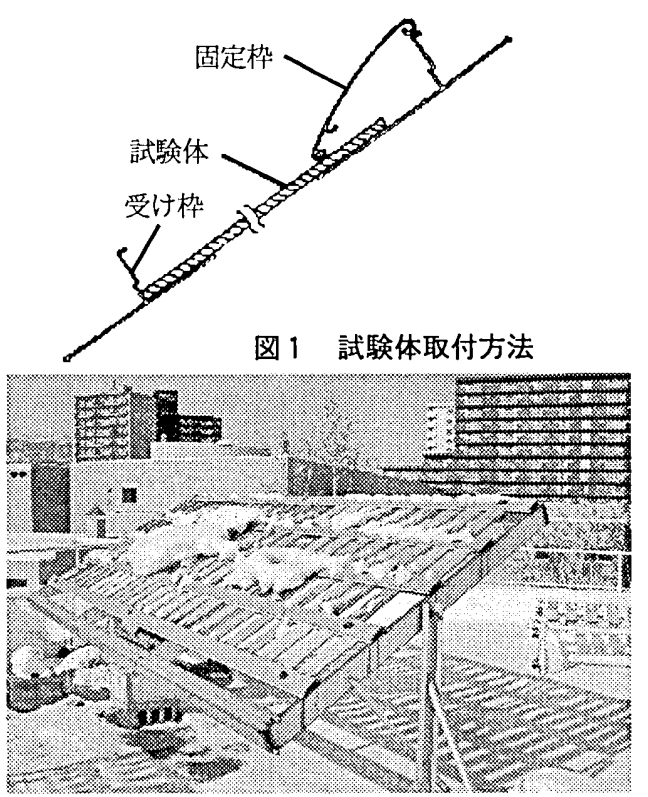

写真1冬期の暴露試験状況(札幌市 2月)

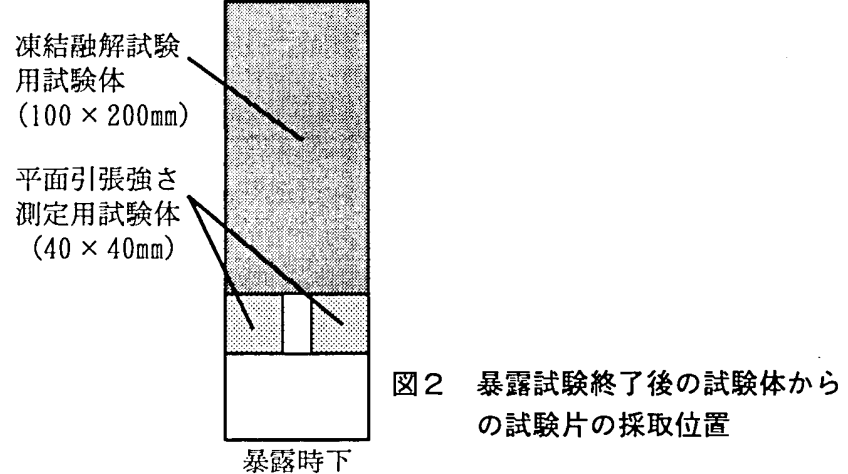

表 2 屋外暴露実験における凍害劣化程度の区分

\begin{tabular}{|c|c|}
\hline 評点 & 凍害少化状況 \\
\hline$\overline{0}$ & 凍害が認められない（污れ、欠け程度） \\
\hline 1 & 凍害の兆候が認められる（軽微なひび割れ、表層の浮き等） \\
\hline 2 & はっきりと凍害が認められる（層間はく離、欠提等） \\
\hline 3 & 著しい谏害が認められる（著しい層間はく離や欠損等） \\
\hline
\end{tabular}

の最低温度は，最低温度が-1.0 ${ }^{\circ} \mathrm{C}$ 以下の期間の最も低い温度とした。 さらに，10年間暴露試験に供された試験体から切断採取した長さ $200 \mathrm{~mm} \times$ 幅 $100 \mathrm{~mm}$ の試験片合計 3 枚と $40 \mathrm{~mm} \times 40 \mathrm{~mm}$ の試験片合計 6 枚 を用いて促進凍結融解試験と平面引張強さ試験を行った。試験片は 原則として図 2 に示す位置から採取し，凍害によるはく離発生部や 欠損部はできるだけ避けた。

(4)劣化判定と凍害劣化度の定義

促進凍結融解試験では外観（表面はく離面積および層間はく離程 度)と厚さ变化率を指標として谏害の評価を行っているが，本研究で の屋外暴露試験では 3.2 (3)で述べる理由により厚さ变化率を指標 とすることは困難であった。このため，屋外暴露試験における凍害劣 化の程度を外観で評価することとし，凍害少化の程度を表 2 に示す 区分に基づいて判定し，3 個の試験体の評点の平均值をそのサイデ イングの評点とした。さらに，得られた評点が 2 以上の場合，凍害が 生じたものと判断し、評点が 2 以上に至った暴露年数 (10年目の評 点が 2 末満の場合は 10 年)で評点を除した值を凍害劣化度と定義し， 以後の険討に用いた。凍害劣化の程度の例を写真 2 に示す。 


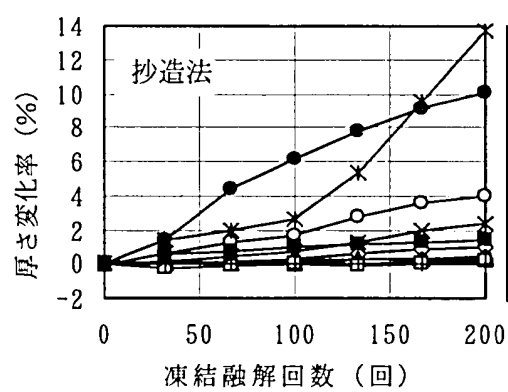

凍結融解回数（回）
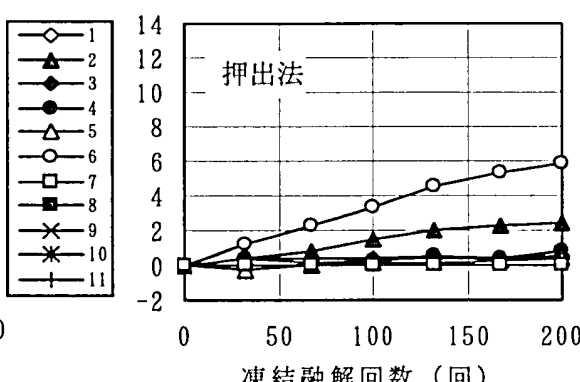

凍結融解回数（回）

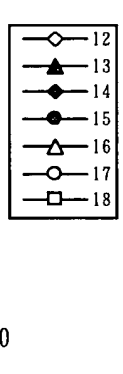

図3

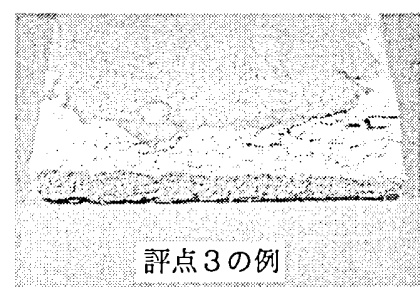

評点 2 の例

評点 3 の例

写真2 屋外暴露試験における凍害劣化の例

3. 実験結果

3. 1 促進凍結融解試験

(1) 外観

外観観察結果を表 3 に示す。21種類中18種類は，JIS A $5422^{-1995}$ に規定された外観上の耐凍結融解性能を満足していた。表面はく離 面㩧が $2 \%$ 以上なったのは抄造法で成形された 2 種頪のみであった。 表面はく離の形態は，直径数林程度の無数の表層はく離が生じるも の(試験体番号 8) と，厚さの增加に伴って表面が脆弱化しはく離す るもの(試験体番号10)とであった。また，著しい層間はく離は，抄 造法の 1 種類 (試験体番号 10) と押出法の 1 種類 (試験体番号 17) に 見られ，厚さ变化率が $5 \%$ を超えたあたりから観察された。しかし， 厚さ变化率が $10 \%$ 超えても著しい層間はく㠍が観察されないもの （試験体番号 4) もあった。

(2) 厚さ変化率

試験体の厚さ変化率を図 3 に示す。厚さ変化率がJIS A $5422^{-1995}$ の疎凍害性能基準である $10 \%$ を超えたのはいずれも抄造法成形品 で, ハウスメーカー向けの試作品(試験体番号 4) と温暖地限定品(試 験体番号10)の2種類であった。200サイクル時の厚さ变化率は，抄 造法による成形品では先の 2 例を除いておよそ0〜 4\%の範囲にあ った。押出法成形品ではおよそ0〜6\%で，2例を除くとほほ $1 \%$ 以 下であった。マット法成形品ではおよそ1〜3\%であった。このよう に，促進凍結融解試験条件では成形法等にかかわらず大多数のサイ ディングが優れた耐谏害性を示した。

また, 凍結融解回数と厚さ変化率の関係は，200サイクル時の厚さ 变化率が10\%を超えるものを除くと，ほほ原点を通る直線となった。 このため, ある凍結融解回数終了時の厚さ变化率からその後の厚さ 変化率を推定することでき，スクリーニング等を目的とした場合な どでは簡易で迅速な耐凍害性評価が可能と考えられる。

\section{2 屋外暴露試験}

\section{(1)試験体に生じる最低温度別の凍結融解回数}

表 4 に屋外暴露期間中の試験体に生じた凍結融解回数の年平均值 を最低温度別に示す(一部欠測期間あり)。札幌市や上磯町では，そ れぞれ年113回，103回の凍結融解がある。そのうち100回，94回は 最低温度 $-10^{\circ} \mathrm{C}$ 末満での凍結融解であり, JIS法での涷結最低温度で
表3 促進凍結融解試験における外観観察結果

\begin{tabular}{|c|c|c|c|c|c|c|}
\hline \multirow{2}{*}{$\begin{array}{c}\text { 試験体 } \\
\text { 番号 }\end{array}$} & \multicolumn{2}{|r|}{4} & \multicolumn{4}{|c|}{ 数 } \\
\hline & 32 & 67 & 100 & 133 & 167 & 200 \\
\hline 1 & 0 & 0 & 0 & 0 & 0 & 0 \\
\hline 2 & 0 & 0 & 0 & 0 & 0 & 0 \\
\hline 3 & 0 & 0 & 0 & 0 & 0 & 0 \\
\hline 4 & 0 & 0 & 0 & 0 & 0 & 0 \\
\hline 5 & 0 & 0 & 0 & 0 & 0 & 0 \\
\hline 6 & 0 & 0 & 0 & 0 & 0 & 0 \\
\hline 7 & 0 & 0 & 0 & 0 & 0 & 0 \\
\hline 8 & 0 & 0 & 0 & 0 & 0 & $\mathbf{A}$ \\
\hline 9 & 0 & 0 & 0 & 0 & 0 & 0 \\
\hline 10 & 0 & 0 & 0 & 0 & $\mathbf{B}$ & $\Delta$ \\
\hline 11 & 0 & 0 & 0 & 0 & $\overline{0}$ & 0 \\
\hline 12 & 0 & 0 & 0 & 0 & 0 & 0 \\
\hline 13 & 0 & 0 & 0 & 0 & 0 & 0 \\
\hline 14 & 0 & 0 & 0 & 0 & 0 & 0 \\
\hline 15 & 0 & 0 & 0 & 0 & 0 & 0 \\
\hline 16 & 0 & 0 & 0 & 0 & 0 & 0 \\
\hline 17 & 0 & 0 & 0 & b & $\mathbf{E}$ & D \\
\hline 18 & 0 & 0 & 0 & 0 & 0 & 0 \\
\hline 19 & 0 & 0 & 0 & 0 & 0 & 0 \\
\hline 20 & 0 & 0 & 0 & 0 & 0 & 0 \\
\hline 21 & 0 & 0 & 0 & 0 & 0 & 0 \\
\hline
\end{tabular}

表4 暴露試験体に生じた最低温度別凍結融解回数の年平均值

\begin{tabular}{|c|c|c|c|c|c|c|}
\hline \multirow{2}{*}{\begin{tabular}{c} 
暴露 \\
\cline { 2 - 6 }
\end{tabular}} & $\begin{array}{c}-1{ }^{\circ} \mathrm{C} \geqq \theta \\
>-5^{\circ} \mathrm{C}\end{array}$ & $\begin{array}{c}-5{ }^{\circ} \mathrm{C} \geqq \theta \\
>-10^{\circ} \mathrm{C}\end{array}$ & $\begin{array}{c}-10^{\circ} \mathrm{C} \geqq \theta \\
>-15^{\circ} \mathrm{C}\end{array}$ & $\begin{array}{c}-15^{\circ} \mathrm{C} \geqq \theta \\
>-20^{\circ} \mathrm{C}\end{array}$ & $-20^{\circ} \mathrm{C} \geqq \theta$ & \multirow{2}{*}{ 合計 } \\
\hline 札幌市 & 51 & 49 & 13 & 1 & 0 & 113 \\
\hline 上磯町 & 63 & 31 & 9 & 1 & 0 & 103 \\
\hline 北見市 & 48 & 37 & 28 & 21 & 7 & 141 \\
\hline
\end{tabular}

ある $-20^{\circ} \mathrm{C}$ 相当の凍結融解は 1 回程度しかない。北見市は, 年間凍結 融解回数 141 回のうち, $-10^{\circ} \mathrm{C}$ 末満の凍結融解回数は 85 回と 3 都市の 中で最も少なく， $-20^{\circ} \mathrm{C}$ 程度の凍結融解回数は 28 回と最も多くなって いる。この結果，最低温度や凍結融解回数に関しては北見市の暴露環 境が最も笽しく，次いで札幌市，上磯町の順と言える。

（2）外観上の凍害劣化状況

屋外暴露試験における凍害劣化の評点と凍害劣化度を表 5 に示す。

抄造法による成形品は暴露開始後 2 ～5年目で凍害を生じ， 1 種 類（試験体番号 11）を除いて評点 3 となり，著しい劣化が観察され た。凍害は試験体下辺から生じはじめ，層間はく離や表層部のはく離 が徐々に進行し，広い籍囲の素材の欠損に至った。凍害劣化度は 0.3 〜 1.0であった。

押出法による成形品は，凍害劣化が観察されたもの(試験体番号 12.13と17の一部) と観察されないもの（試験体番号 14，15，16, 18）に分かれた。凍害劣化の評点が 2 以上の試験体では暴露開始後 5 〜6年目から劣化が顕在化し，試験体端部に微細なひび割れを生じ 
表 5 屋外暴露試験における凍害劣化の評点と凍害劣化度

\begin{tabular}{|c|c|c|c|c|c|c|c|c|c|c|}
\hline \multirow{2}{*}{$\begin{array}{l}\text { 成 } \\
\text { 形 } \\
\text { 法 } \\
\end{array}$} & \multirow{2}{*}{$\begin{array}{l}\text { 試呀体 } \\
\text { 番号 }\end{array}$} & \multirow{2}{*}{$\begin{array}{l}\text { 暴灌 } \\
\text { 所 }\end{array}$} & \multicolumn{7}{|c|}{ 暴 露 年 数 (年) } & \multirow{2}{*}{ 栥宫 } \\
\hline & & & 2 & 3 & 4 & 5 & 6 & 8 & 10 & \\
\hline \multirow{33}{*}{$\begin{array}{l}\text { 抄 } \\
\text { 法 }\end{array}$} & \multirow{3}{*}{1} & 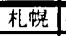 & 2.0 & 3.0 & 3.0 & 3.0 & \multirow{3}{*}{\multicolumn{3}{|c|}{ 柊了 }} & 1 \\
\hline & & 上破 & 1.0 & 2.0 & 3.0 & 3.0 & & & & 0.7 \\
\hline & & 北見 & 0.3 & 2.3 & 3.0 & 3.0 & & & & \\
\hline & \multirow{3}{*}{2} & 机婏 & 1.0 & 2.0 & 3.0 & 3.0 & \multirow{3}{*}{\multicolumn{3}{|c|}{ 数 }} & 0.7 \\
\hline & & 上破 & 0.0 & 1.3 & 2.0 & 3.0 & & & & 0.5 \\
\hline & & 北見 & 0.0 & 1.3 & 2.3 & 3.0 & & & & 0.6 \\
\hline & \multirow{3}{*}{3} & 札蛙 & 0.7 & 2.7 & 3.0 & 3.0 & & & & 0.9 \\
\hline & & 上䂸 & 1.0 & 2.0 & 2.7 & 3.0 & & 柊了 & & 0.7 \\
\hline & & 北見 & 1.0 & 1.7 & 2.7 & 3.0 & & & & 0.7 \\
\hline & & 札㹸 & 1.0 & 2.3 & 3.0 & 3.0 & & & & 0.8 \\
\hline & 4 & 上磯 & 1.0 & 2.3 & 2.7 & 3.0 & & $k\}$ & & 0.8 \\
\hline & & 北見 & 0.0 & 2.0 & 2.0 & 3.0 & & & & \\
\hline & & 札䝟 & 0.0 & 1.0 & 1.7 & 2.5 & 2.5 & 3.0 & 3.0 & 0.5 \\
\hline & 5 & 上䂪 & 0.0 & 0.0 & 1.0 & 2.3 & 3.0 & 3.0 & 3.0 & 0.5 \\
\hline & & 北見 & 0.0 & 0.0 & 1.0 & 1.3 & 1.3 & 2.0 & 3.0 & 0.3 \\
\hline & & 私配 & 0.0 & 0.3 & 1.0 & 3.0 & $3: 0$ & 3.0 & 3.0 & 0.6 \\
\hline & 6 & 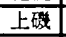 & 0.0 & 0.0 & 1.0 & 1.0 & 1.3 & 1.3 & 3.0 & 0.3 \\
\hline & & 北見 & 0.0 & 0.0 & 0.0 & 0.3 & 1.3 & 2.3 & 3,0 & 0.3 \\
\hline & & 机䣲 & 1.0 & 2.0 & 3.0 & 3.0 & 3.0 & 3.0 & 3.0 & 0.7 \\
\hline & 7 & 上磯 & 0.0 & $\begin{array}{ll}1.3 \\
\end{array}$ & 2.0 & 3.0 & 3.0 & 3. & 3.0 & 0.5 \\
\hline & & 北見 & 1.0 & 2.0 & 2.0 & 2.0 & 3.0 & 3.0 & 3.0 & 0.7 \\
\hline & & 札蛙 & 1.0 & 1.3 & 2.0 & 3.0 & 3.0 & 3.0 & 3.0 & 0.5 \\
\hline & 8 & 上璣 & 0.0 & 1.0 & 2.0 & 2.3 & 3.0 & 3.0 & 3.0 & 0.5 \\
\hline & & 北見 & 0.0 & 1.3 & 1.3 & 1.7 & 2.0 & 3.0 & 3.0 & 0.3 \\
\hline & & 私㭬 & 0.0 & 1.7 & 2.0 & 3.0 & 3.0 & 3.0 & 3.0 & 0.5 \\
\hline & 9 & 上场 & 0.0 & 1.0 & 1.3 & 3.0 & 3.0 & 3.0 & 3.0 & 0.6 \\
\hline & & 北見 & 0.0 & 1.3 & 2.0 & 2.3 & 3.0 & 3.0 & 3.0 & 0.5 \\
\hline & & 札㹸 & 0.0 & 3.0 & 3.0 & 3.0 & & & & 1.0 \\
\hline & 10 & 上磯 & 1.3 & 3,0 & 3.0 & 3.0 & & 終 T & & 1.0 \\
\hline & & 北見 & 2.0 & 3.0 & 3.0 & 3.0 & & & & 1.0 \\
\hline & & 札溌 & 0.0 & 0.0 & 0.0 & 0.0 & 0.0 & 0.0 & 0.0 & 0.0 \\
\hline & 11 & 上䂝 & 0.0 & 0.0 & 0.0 & 0.0 & 0.0 & 0. & 0.0 & 0.0 \\
\hline & & 北見 & 0.0 & 0.0 & 0.0 & 0.0 & 0.0 & 0.0 & 0.0 & 0.0 \\
\hline & & 札嘫 & 0.0 & 1.0 & 1.7 & 2.0 & 2.5 & 3.0 & 3.0 & 0.4 \\
\hline & 12 & 上㙨 & 0.0 & 0.3 & 1.0 & 2.0 & 2.3 & 3.0 & 3.0 & 0.4 \\
\hline & & 北見 & 0.0 & 0.0 & 0.0 & 1.0 & 1.3 & 1.3 & 2.0 & 0.2 \\
\hline & & 机幙 & 0.0 & 0.0 & 1.0 & 1.5 & 3.0 & 3.0 & 3.0 & \\
\hline & 13 & 上灣 & 0.0 & 0.0 & 0.0 & 0.0 & 0.0 & 0.0 & 2.0 & 0.2 \\
\hline & & 北見 & 0.0 & 0.0 & 0.0 & 0.3 & 2.0 & 2.3 & 3.0 & 0.3 \\
\hline & & 机嘅 & 0.0 & 0.0 & 0.0 & 0.0 & 0.0 & 0.5 & 1.0 & 0.1 \\
\hline & 14 & 上磯 & 0.0 & 0.0 & 0.0 & 0.0 & 0.0 & 0.0 & 1.0 & 0.1 \\
\hline & & 北見 & 0.0 & 0.0 & 0.0 & 0.0 & 0.0 & 0.3 & 1.0 & \\
\hline 押 & & 札幙 & 0.0 & 0.0 & 0.0 & 0.0 & 0.0 & 0.0 & 0.0 & 0.0 \\
\hline 出 & 15 & 上䂭 & 0.0 & 0.0 & 0.0 & 0.0 & 0.0 & 0 . & 0.0 & 0.0 \\
\hline 法 & & 北見 & 0.0 & 0.0 & 0.0 & 0.0 & 0.0 & 0.0 & 0.0 & 0.0 \\
\hline & & 机㹸 & 0.0 & 0.0 & 0.0 & 0.0 & 0.0 & 7 & 0.0 & 0.0 \\
\hline & 16 & \begin{tabular}{|l|} 
上磯 \\
\end{tabular} & 0.0 & 0.0 & 0.0 & 0.0 & 0.0 & 0.0 & 0.0 & 0.0 \\
\hline & & 北見 & 0.0 & 0.0 & 0.0 & 0.0 & 0.0 & 0.0 & 0.0 & 0.0 \\
\hline & & 札蟙 & 0.0 & 0.0 & 0.0 & 0.0 & 0.0 & 0. & 0.0 & 0.0 \\
\hline & 17 & \begin{tabular}{|l|} 
上碚 \\
\end{tabular} & 0.0 & 0.0 & 0.0 & 0.0 & 0.0 & 1.0 & 1.7 & 0.2 \\
\hline & & 北見 & 0.0 & 0.0 & 0.0 & 0.0 & 0.0 & 0. & 1.7 & 0.2 \\
\hline & & 札蛙 & 0.0 & 0.0 & 0.0 & 0.0 & 0.0 & 0.0 & 0.0 & 0.0 \\
\hline & 18 & 上磯 & 0.0 & 0.0 & 0.0 & 0.0 & 0.0 & 0 & 0.0 & 0.0 \\
\hline & & 北見 & 0.0 & 0.0 & 0.0 & 0.0 & 0.0 & 0.0 & 0.0 & 0.0 \\
\hline & & 㠸炷 & 0.0 & 0.0 & 0.0 & 0.0 & 0.5 & 1.0 & 1.0 & 0.1 \\
\hline & 19 & 上璣 & 0.0 & 0.0 & 0.0 & 0.0 & 0.0 & 0.3 & 0.3 & 0.0 \\
\hline & & 北見 & 0.0 & 0.0 & 0.0 & 0.0 & 0.0 & 0.3 & 0.3 & 0.0 \\
\hline & & 札 & 0.0 & 0.0 & 0.0 & 0.0 & 0.0 & 0.0 & 0.0 & 0.0 \\
\hline 卜 & 20 & 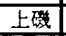 & 0.0 & 0.0 & 0.0 & 0.0 & 0.0 & 0.0 & 0.0 & 0.0 \\
\hline 法 & & 北見 & 0.0 & 0.0 & 0.0 & 0.0 & 0.0 & 0.0 & 0.0 & 0.0 \\
\hline & & 札㹸 & 0.0 & 0.0 & 0.0 & 0.0 & 0.0 & 0.0 & 0.0 & 0.0 \\
\hline & 21 & 上碭 & 0.0 & 0.0 & 0.0 & 0.0 & 0.0 & 0.0 & 0.0 & 0.0 \\
\hline & & 北見 & 0.0 & \begin{tabular}{l|l}
0.0 \\
\end{tabular} & 0.0 & 0.0 & 0.0 & 0.0 & 0.0 & 0.0 \\
\hline
\end{tabular}

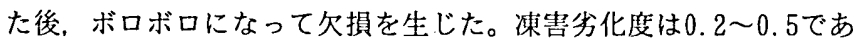
った。

マット法成形品の評点は 0.0 1.0で涷害劣化は钼察されず，比較 的優れた耐凍害性を示した。

(3) 厚さ変化

暴露試験体の厚さ変化を図 4 に示す。困の中で，黑く塗りつぶした 点は凍害が顕在化したことを示している。

厚さ変化率は，概して谏害の顥在化との間に相関性があり，厚さ变 化率が増大すると凍害が顥在化してくる傾向にある。しかし，厚さ变
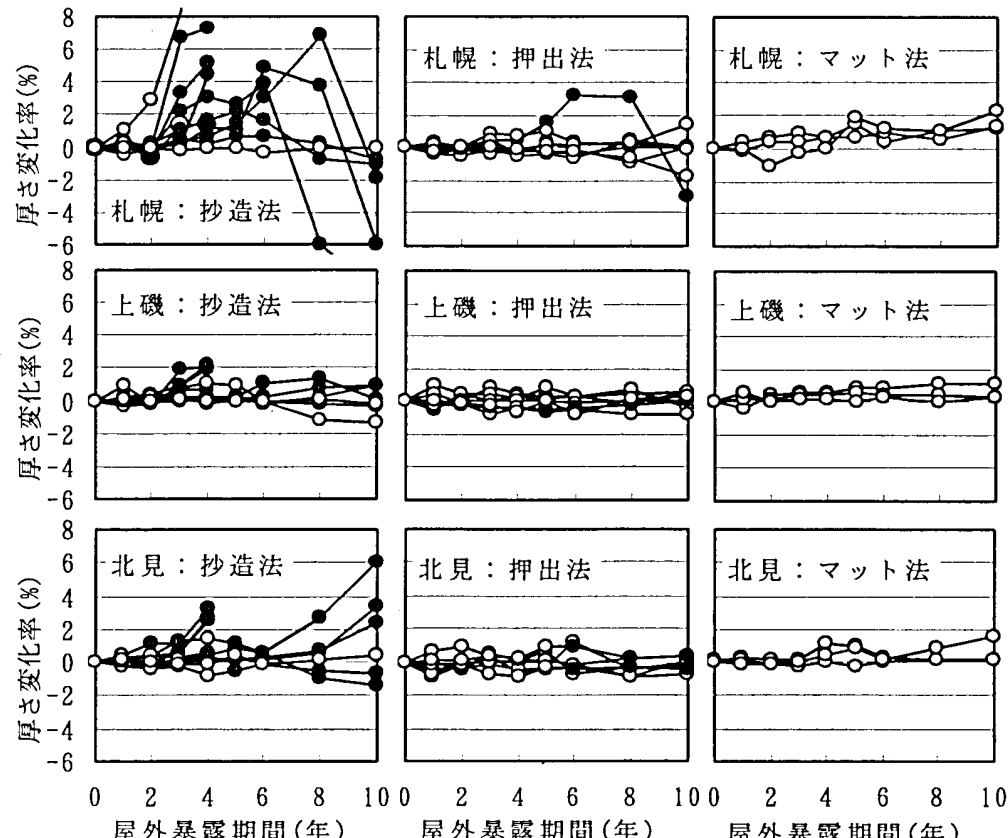

図4 屋外暴露試験における厚さ変化率

化率が小さくても凍害が見られる場合もある。その理由は，凍害は試 験体の下辺から生じ始め，その後上方に広がっていくが，厚さ変化率 は試験体下边から $20 \mathrm{~mm}$ の位置で测定されており，凍害の発生位置と 厚さ変化率の测定位置とのあいだにずれがあるためと思われる。こ のため，暴露試験体の厚さ测定は，凍害が発生し始める位置にできる だけ近い位置で行うのが望ましいと考える。なお，厚さ变化率が增加 した後, 大きく減少に転じているのは谏害により素材が欠損したた めである。

\section{3 屋外暴露試験後の試験体による試験}

(1) 促進凍結融解試験による厚さ変化

屋外暴露試験後の試験体から切り出した試験片の促進凍結融解試 験による厚さ変化率を図 5 に，暴露試験前の厚さ変化率と暴露試験 後の厚さ変化率の関係を図 6 に示す。抄造法成形品は，暴露後の厚さ 変化率が暴露前と比較して大幅に增加する傾向があり，押出法成形 品の一部にも，抄造法成形品ほどではないが暴露後の厚さ变化率が 增加するものがある。特に，暴露期間中に凍害が顕在化した試験片に おいて厚さ変化率の增加が顕著であり，暴露によって耐凍害性能が 低下したものと考えられる。マット法成形品では，暴露前と暴露後で 厚さ変化率の相连は少ない。

(2) 平面引張り強さ

図 7 に暴露試験前と暴露試験後の平面引張強さの関係を示す。平 面引張強さ $3 \mathrm{~N} / \mathrm{mm}^{2}$ 以下では，ばらつきはあるがこれらの関係に特別 な傾向は見られなかった。 $3 \mathrm{~N} / \mathrm{mm}^{2}$ 以上では，暴露後の強さが低下す る傾向にあった。その場合，サイディング表層の薄皮が剥がれるごと く極めて表面に近い位固で破断を生じ，試験片の内部で破断を生じ た他のサイディングとは異なる破断形態であった。

4. 考察

(1)サイディングの耐凍害性

屋外暴露試験における凍害劣化度と見掛け密度の関係を図 8 に示す。 ここで, 凍害劣化度 0.2 未满の点は屋外暴露試験で涷害劣化が見られ 

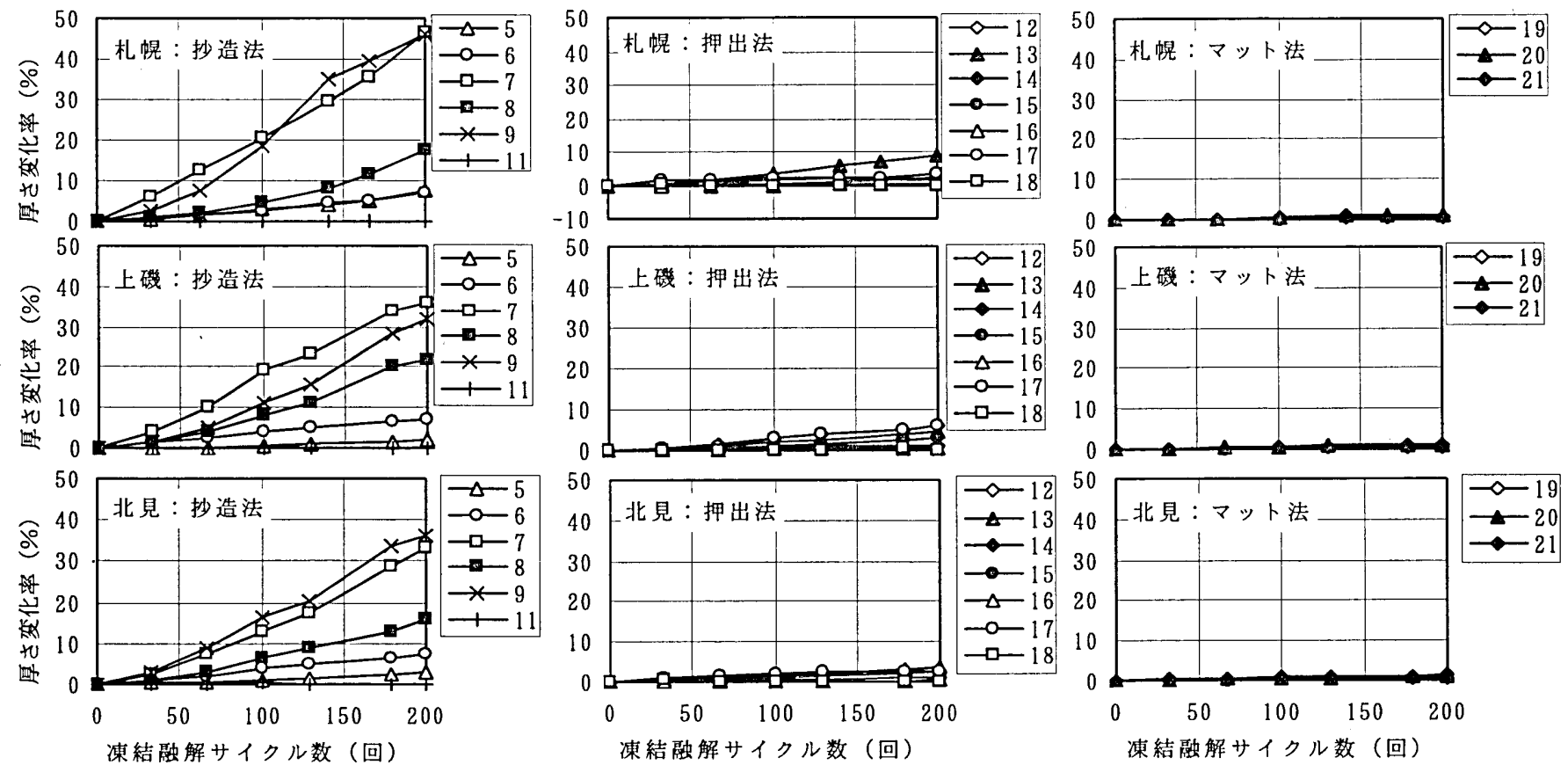

図 5

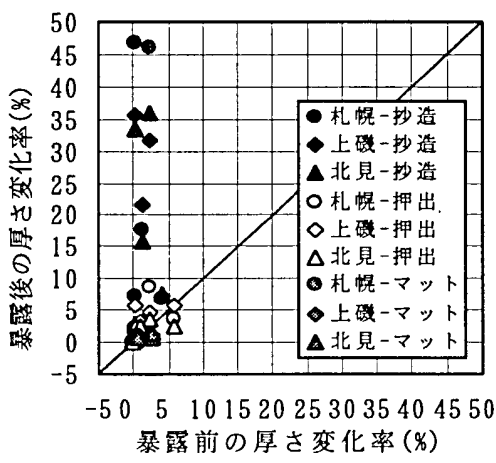

図6

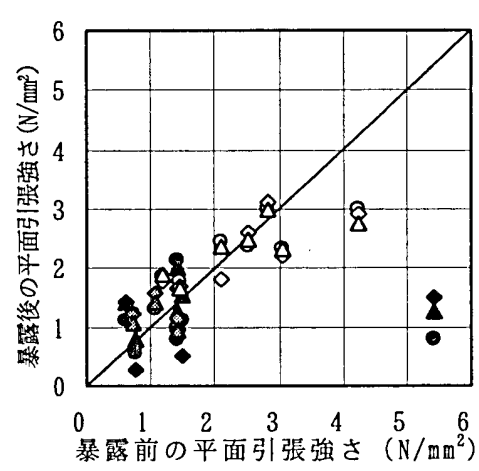

因 7 屋外暴露前後の平面引張強さ の比較

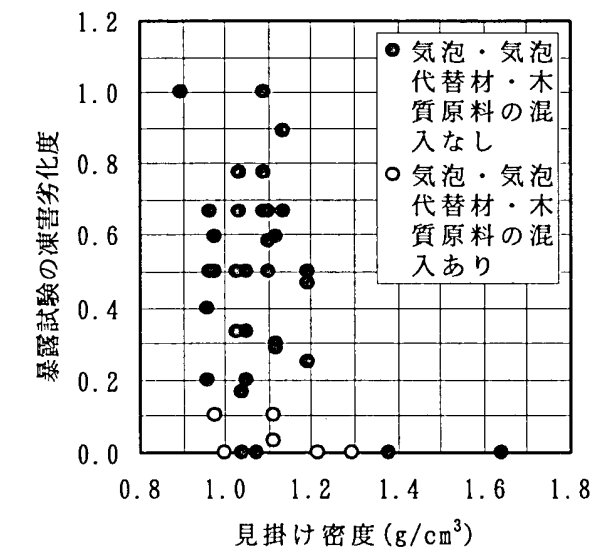

図8 見掛け密度と暴露試験の凍害劣化度の関係

なかった試験体である。見掛け密度が $1.2 \mathrm{~g} / \mathrm{cm}^{3}$ 以上の試験体は，屋 外暴露試験において耐凍害性に優れる結果となった。一般に，セメン ト硬化体では密度が大きくなるに従って組織が緻密になり，耐凍害 性が向上する傾向にある。見掛け密度が $1.2 \mathrm{~g} / \mathrm{cm}^{3}$ 以上であればいか なるサイディングも耐凍害性に優れると結論づけることはできない が，図9の(a)と（b)に示すように，見掛け密度の大きいサイディン グの空隙構造は緻密であり空隙率も小さいため, 凍害防止に有利と
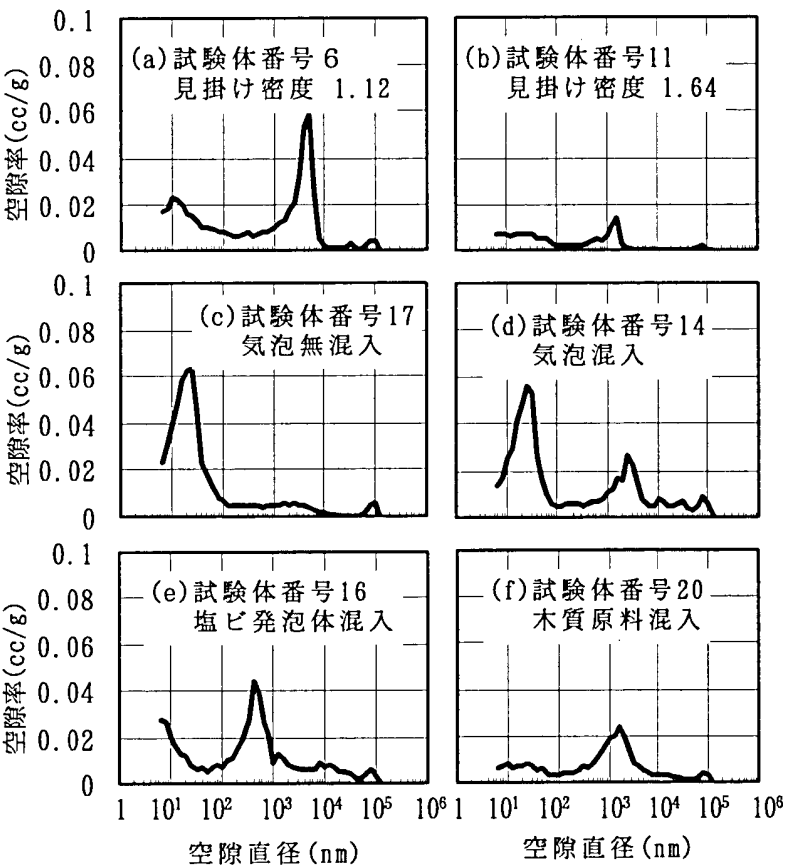

図9サイディングの空隙径分布

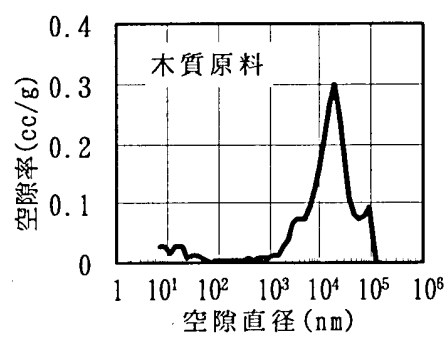

図10 木質原料の空隙径分布

なることから、このような結果になったものと考えられる。

また，気泡や塩ビ発泡体，木質原料が混入された試験体の耐凍害性 も俊れる結果となった。図 9 の (d), (e)に示すように，気泡や塩ビ 
表 6

\begin{tabular}{|c|c|c|c|}
\hline & 凍害劣化度 & $\begin{array}{c}\text { 厚さ変化率 } \\
(\%)\end{array}$ & $\begin{array}{c}\text { 平面引張強さ } \\
\left(\mathrm{N} / \mathrm{mm}^{2}\right)\end{array}$ \\
\hline 札幌市 & 0.39 & 8.99 & 1.67 \\
\hline 上磯町 & 0.33 & 7.68 & 1.65 \\
\hline 北見市 & 0.30 & 6.97 & 1.76 \\
\hline
\end{tabular}

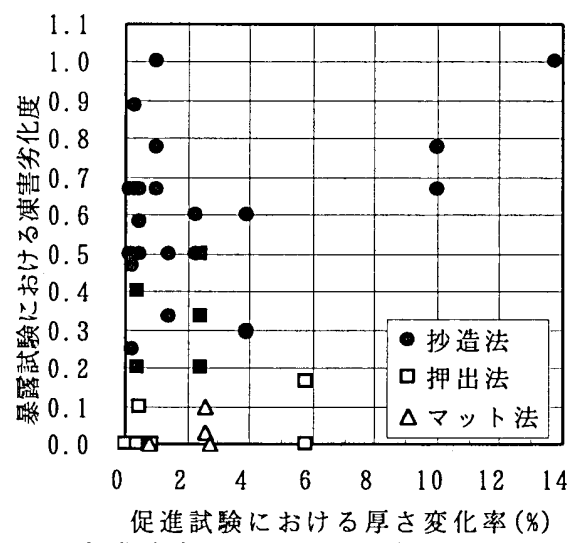

图11促進試験における厚さ変化率と暴露試験に おける凍害劣化度の関係

発泡体が混入された試験体では，直径400 2500nm付近にピークを 持つ空隙が認められるのに対し，気泡や塩ビ発泡体を含まない試験 体(図 9 の (c))では認められない。このため,これらの空隙は気泡 または塩ビ発泡体の混入の影響によるものと推察され、これらの混 入が凍害防止に寄与したものと思われる。

木質原料を混入した試験体（試験体番号 19，20，21）では，因 9 の (f)の例のように直径1600 2500nm付近に空隙のピークが認めら れた。木質原料として用いられるスギ材やヒノキ材の仮道管の直径 は5000〜50000nmと言われており4)，図10に示した水銀圧入法によ る空隙径分布の测定結果では約 $19000 \mathrm{~nm}$ 付近に空隙のピークが認め られる。このため, 図9の(f)の空隙のピークは木質原料の混入の影 響によるものと思われ，木質原料中の空隙が凍害防止に寄与したも のと考えられる。

(2) 凍害劣化の地域間の相違

道内 3 か所の暴露場所での暴露試験における凍害劣化度，暴露試 験後の厚さ変化率および平面引張強さの平均値を表 6 に示す。凍害 劣化度および厚さ変化率は，札幌市が最も大きく，次いで上磯町，北 見市の順となり，平面引張強さは，上磯町が最も小さく，次いで札幌 市，北見市の順となった。この結果は，凍害劣化の外力である凍結融 解回数の計算結果および最低温度の測定結果(表 4)から想定された 傾向(北見市が最も笽しく，上磯町が最も稳やか)と一致しない。一 般に，凍害はある限界以上に含水が高まってくると発生することか 5. 凍害の発生には十分な水分の存在が必須である。ここで，暴露場 所に最も近いアメダス観測所で測定された暴露期間中の冬期間 (10 月 1 日から 4 月 30 日まで)の降水量の平均值を比較すると、札幌市 が659mmと最も多く，次いで上磯町の $531 \mathrm{~mm} ，$ 北見市の $362 \mathrm{~mm}$ の順と なり，北見市の降水量は札幌市の約 $55 \%$ であった。降水量とサイデ ィングの含水程度を直接的に結びつけるデータは無いが, 降水量が 多いほど凍害を生じる含水量となる期間が長くなることは容易に想 像されることから，降水量が最も多い札幌市の凍害劣化が 3 地域の なかで最も大きくなり，降水量の少ない北見市が小さくなったもの
と考えられる。

(3) 促進試験試験結果と屋外暴露試験結果の相関性

JIS A 5422-1995に規定された促進凍結融解試験による耐凍害性試 験結果と屋外環境での凍害劣化度との間に相関性があるか否かを検 討した。促進試験で生じる凍害劣化のうち，表面はく離や層間はく離 は厚さ变化率と相関性があることから，促進試験による凍害劣化程 度を厚さ変化率で代表することとし，屋外暴露試験における凍害劣 化度との関係を示したのが図11である。促進試験における厚さ変化 率が大きい訌験体ほど屋外暴露試験における凍害劣化度が大きい傾 向にあるなら，図11で正の相関が認められるはずである。一部にそ のような傾向があるものの，多くの試験体で相関は認めらなかった。 特に，凍害劣化を生じなかった試験体と同程度以下の厚さ变化率で ありながら，屋外暴露試䍄において早期に凍害劣化を生じた試験体 が多数見られた。この結果は，一部のサイディングの耐凍害性は，促 進凍結融解試験では考虑されていない環境要因の影響を受ける可能 性のあることを示唆している。今後は、コンクリートの凍害に関する 研究で指摘されている夏期の乾燥(5)や. 西野ら ${ }^{61.7)}$ が指摘する岑酸化 などについて，サイディングの凍害への影響の有無を検討していく。

\section{5. まとめ}

本実験は，平成 7 年に主に札幌市内で市販されたサイディングに ついて10年間の屋外暴露試験と促進凍結融解試験を行い, 屋外環境 での耐凍害性および屋外暴露試験結果と促進凍結融解試験結果の対 応性を検討したものである。本実験の範用でその結果は次のように まとめられる。

(1) 見掛け密度が $1.2 \mathrm{~g} / \mathrm{cm}^{3}$ 以上のサイディング，気泡・塩ビ発泡体・ 木質原料が混入されたサイディングは, 屋外暴露試験, 促進凍結融解 試験のいずれにおいても優れた耐凍害性を示す。

(2) 促進試験における厚さ变化率と暴露試験における凍害劣化度は 必ずしも相関せず, このため, 促進試験では考虑されていない要因が サイディングの耐凍害性に影響している可能性がある。

\section{謝辞}

本研究は，ナショナル住宅産業梸(現パナホーム秝)との共同研究 として行った内容を拡大発展させたものです。関係者に謝意を表する とともに，研究責任者であった吉田繁夫(現䏫自然素材研究所)，北 川聡の両氏に厚くお礼申し上げます。

\section{参考文献}

1)社団法人日本サッシ協会:住宅用建材使用状況調査.2004.3

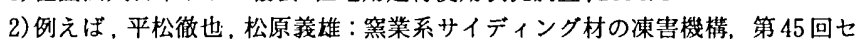
メント技術大会講演集，pp. 526-531.1991

3) 星野雅幸:寒冷地におけるサイディングの暴露試験に関する研究.日本建築学 会大会学術講演梗概集(関東)，pp. 579-580，2001.9

4)独立行政法人森林総合研究所監修、木材工業ハンドブック，丸善獭，2004

5) 田畑雅幸, 平野彰产、泜幸雄：札煶市に長期屋外暴露したコンクリートの和凍 害性について, 日本建築学会北海道支部研究報告集，№.79, pp. 9-12, 2006.7

6) 西野由紀彦, 大羽伸和, 安田延明: 案業系サイディング材の諸物性に及ぼす炭 酸化の影響 (その1凍害の原因調査), 日本建築学会大会学術講演梗概集(関 東), pp. 355-356, 1993

7)安田延明, 大羽伸和, 西野由紀彦: 壘業系サイディング材の諸物性に及ぼす炭

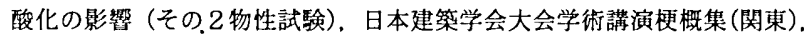
pp. $357-358,1993$

8)吉野利幸:窝業系サイディングの耐凍害性に関する屋外暴露実験, 日本建築学 会北海道支部研究報告集, №. 79, pp. 13-16, 2006.7 